\title{
UPAYA MENINGKATKAN HASIL BELAJAR MATEMATIKA MELALUI MODEL PEMBELAJARAN KOOPERATIF TIPE STAD PADA MATERI HIMPINAN
}

\author{
RUSTINI \\ SMP Negeri 178 Jakarta \\ e-mail: rustini178@gmail.com
}

\begin{abstract}
ABSTRAK
Hasil belajar Matematika siswa SMP Negeri 178 Jakarta masih rendah dan siswa kurang memahami konsep matematika. Rendahnya hasil belajar Matematika siswa SMP Negeri 178 Jakarta disebabkan oleh banyak faktor, di antaranya adalah: 1) siswa masih kurang dalam pemahaman konsep matematika; 2) siswa kurang aktif dan kreatif dalam pembelajaran Matematika.dan 3) penggunaan metode pembelajaran yng kurag tepat. Penelitian ini bertujuan untuk meningkatkan hasil belajar matematka siswa pada materi Himpunan . Penelitian ini dilakukan di SMP Negeri 178 Jakarta dan dilaksanakan pada bulan Agustus s/d Oktober 2018. Jenis penelitian yang digunakan adalah penelitian tindakan kelas yang dilaksanakan selama 3 siklus dan setiap siklus terdiri dari 3 pertemuan.Setiap siklus terdiri dari 4 tahapan yaitu: perencanan, pelaksanaan pengamatan dan refleksi. Teknik pengumpulan data menggunakan analisis deskriptif data berupa tes formatif. Manfaat penelitian ini siswa dapat memahami pentingnya memiliki kemampuan penguasaan konsep pada materi Himpunan. Dari hasil analisis tes formatif menunjukkan nilai rata-rata pada siklus I 66,4 dengan ketuntasan 58,33\%, pada silus II nilai rata-rata 71,94 dengan ketuntasan $72,20 \%$, dan pada siklus III nilai rata-rata 78,89 dengan ketuntasan belajar 91,66\%. Berdasarkan hasil yang diperoleh dapat ditarik kesimpulan bahwa belajar akan bermakna jika anak mengalami sendiri apa yang dipelajari dan adanya kerja sama dalam kelompok memudahkan siswa dalam memahami konsep maka model pembelajaran Kooperatif Tipe STAD mampu meningkatkan hasil belajar matematika pada materi Himpunan dan dapat menciptakan pembelajaran aktif inovatif kreatif dan menyenangkan.
\end{abstract}

Kata Kunci: Belajar, Belajar Matematika, kooperatif tipe STAD

\section{PENDAHULUAN}

Pada proses pembelajaran peneliti menengarai bahwa hasil belajar siswa di SMP Negeri 178 Jakarta untuk pelajaran Matematika masih rendah. Hal ini disebabkan karena sikap siswa yang kurang termotivasi terhadap mata pelajaran tersebut. Penguasaan konsep-konsep dasar Matematika yang rendah dan metode pembelajaran yang digunakan guru pun kurang tepat.

sebagian siswa memiliki pemahaman konsep matematika yang kurang, hal ini terlihat pada sebagian besar materi yang diajarkan dalam pembelajaran matematika. Saat pembelajaran berlangsung siswa tidak berani untuk menanyakan kesulitan dalam memahami materi maupun dalam mengerjakan soal yang diberikan oleh guru. Inisiatif siswa kurang, hal tersebut nampak ketika guru memberi kesempatan kepada siswa untuk bertanya maupun berpendapat tidak dimanfaatkan oleh siswa dengan baik.

Uraian tersebut di atas sangat menarik perhatian peneliti, sehingga dapat dirumuskan masalah sebagai berikut: "Apakah penerapan model pembelajaran kooperatif tipe Student Team Achievemen Devision (STAD) dapat meningkatkan hasil belajar siswa pada materi Himpunan".

Penelitian tindakan kelas ini bertujuan khusus untuk: 1) Untuk mengetahui berapa persentase peningkatan hasil belajar Matematika siswa di kelas VII.7 SMP Negeri 178 Jakarta Tahun Ajaran 2018/2019 semester I ; dan 2) Untuk mengetahui keefektifan proses pembelajaran pada materi himpunan, siswa di kelas VII.7 SMP Negeri 178 Jakarta Tahun Ajaran 2018/2019.

Manfaat penelitian ini: 1) Bagi siswa, untuk membuat siswa termotivasi belajar Matematika dan memahami pentingnya memiliki kemampuan penguasaan materi khususnya pada materi himpunan, Membantu dan melatih siswa agar membiasakan diri dalam kerja 
kelompok, dengan berdiskusi siswa dapat berfikir kritis, saling menyampaikan pendapat dan menyumbangkan pikiranya untuk memecahkan masalah bersama; 2) Bagi guru, sebagai standar acuan dalam meningkatkan profesionalisme sumber daya manusia (SDM) dan membiasakan diri untuk memilih metode yang tepat dalam pembelajaran; dan 3) Bagi sekolah, dapat dijadikan sebagai referensi dalam meningkatkan mutu SMP Negeri 178 Jakarta.

Menurut Gestalt (dalam Yudhawati dan Haryanto, 2011;48) belajar dapat didefinisikan sebagai proses di mana tingkah laku ditimbulkan atau diubah melalui latihan dan pengalaman. Belajar adalah kegiatan yang dilakukan untuk menguasai pengetahuan, kemampuan, kebiasaan, keterampilan dan sikap melalui hubungan baik antara orang yang belajar dengan lingkungannya.

Belajar Matematika adalah suatu usaha yang dilakukan seseorang mengenai bilanganbilangan, susunan, besaran, dan konsep-konsep abstrak yang tersusun secara hierarki untuk memperoleh perubahan kognitif, afektif dan psikomotor berdasarkan pengalaman-pengalaman yang dialami individu tersebut (PPPPTK 2016, 1). Pengetahuan Matematika diperlukan agar seseorang dapat melakukan pemecahan masalah yang abstrak dan praktis dengan menggunakan pola dan hubungan yang berlaku secara formal maupun non formal.

Untuk memudahkan proses pembelajaran matematika agar berdampak optimal bagi siswa diperlukan model pembelajaran yang tepat. Menurut Isjoni (Donni Juni Priansa 2017) model pembelajaran kooperatif tipe Student Teams Achievement Division (STAD) mengubah perilaku belajar dari individualistik menjadi kerja sama tim yang mendorong peserta didik untuk saling membantu dengan yang lainnya.. Model pembelajaran kooperatif tipe Student Teams Achievement Division (STAD )adalah model pembelajaran yang lebih mengedepankan siswa pada kerja dalam kelompok belajar. Dalam pembelajaran kooperatif STAD siswa belajar dalam kelompok-kelompok kecil, siswa yang kurang mampu dapat terbantu dalam memahami materi, maka model pembelajaran kooperatif STAD ini diharapkan mampu meningkatkan semangat belajar siswa dan dapat mempermudah siswa dalam memahami konsep matematika.

\section{METODE PENELITIAN}

Penelitian dilaksanakan di SMP Negeri 178 Jakarta Jalan Mawar I No. 6A Kelurahan Bintaro, Kecamatan Pesanggrahan, Jakarta Selatan. Waktu penelitian ini dimulai dari bulan Agustus s.d. Oktober 2018. Subjek penelitain adalah peserta didik kelas VII.7 SMP Negeri 178 Jakarta sebanyak 36 orang, dengan rincian peserta didik laki-laki sebanyak 13 orang dan peserta didik perempuan sebanyak 23 orang.

Adapun desain penelitain yang peneliti gunakan adalah desain yang disusun oleh Kemmis dan MC Taggart (dalam Rochiati Wiriaatmadja, 2012) 


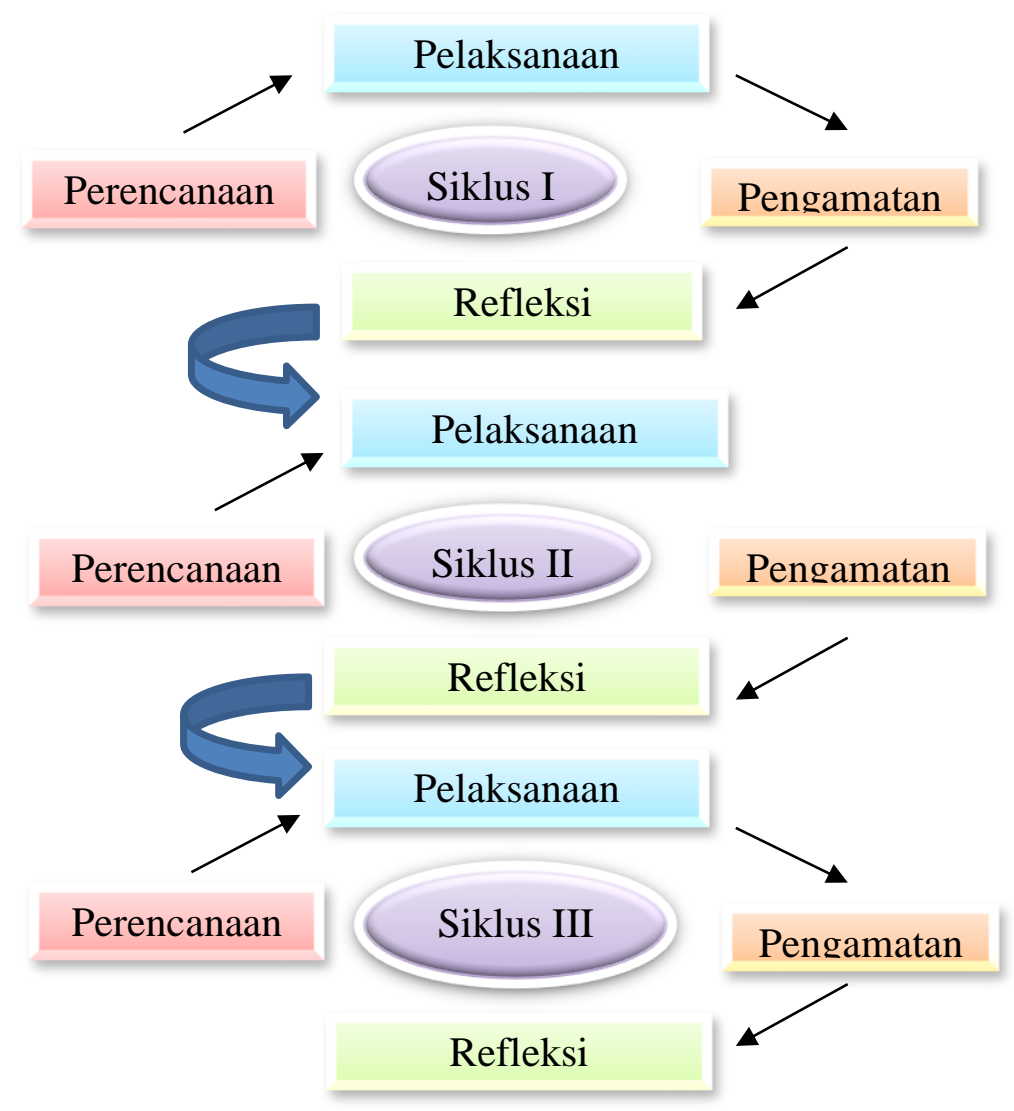

Gambar 1. Model Spiral PTK menurut Kemmis dan Mc Taggart

Penelitian tindakan kelas ini dilaksanan dalam 3 siklus kegiatan, yakni siklus I, II, dan III. Masing-masing siklus terdiri dari tiga pertemuan. Langkah-langkah pada setiap siklus meliputi: (1) perencanaan ( planning); (2) pelaksanaan (acting); (3) pengamatan (observation); dan refleksi (reflecting). Penelitian tindakan kelas ini menggunakan pola kerja kolaborator antara peneliti dengan teman sejawat (guru Matematika). Siklus I berfokus pada materi konsep Himpunan, cara menyatakan himpunan, dan diagram Venn, pada siklus II materi bilangan kardinal, himpunan bagian, dan pada siklus III materi himpunan irisan, gabungan, komplemen dan selisih. Pada siklus I peneliti merancang pembelajaran dengan model kooperatif tipe STAD, Pada siklus II, peneliti merancang pembelajaran berdasarkan hasil observasi dan refleksi pada siklus I dengan membuat perencanaan penelitian tindakan yang sesuai dengan permasalahan yang sebelumnya pernah dikaji. Pada siklus III. Rencana pembelajaran berdasarkan hasil observasi dan refleksi pada siklus II. Teknik pengumpulan data dilakukan melalui tes tertulis, observasi, dan catatan lapangan pada setiap siklusnya dan dilengkapi foto kegiatan. Instrumen pengumpulan data terdiri dari tes tertulis/lembar tes, lembar observasi,lembar catatan lapangan, dokumentasi (kamera).Sumber data terdiri dari data kualitatif dari hasil observasi, data kuantitatif berupa hasil belajar siswa yang diambil dari nilai tes

Penelitian ini dianggap berhasil jika model pembelajaran kooperatif tipe Student Teams Achievement Division (STAD) yang dilaksanakan dapat meningkatkan hasil belajar Matematika siswa kelas VII.7 SMP Negeri 178 Jakarta pada materi himpunan . Untuk keberhasilan penelitian ini, peneliti menganalisis data evaluasi siklus hasil belajar Matematika,lalu dipersentasekan ,minimal siswa mencapai nilai Kriteria Keuntasan Minimal (KKM) sebesar $85 \%$ dari 36 orang siswa atau sejumlah 31 anak yang berhasil mendapatkan nillai sesuai Kriteria Ketuntasan Minimal (KKM) sebesar 70 atau melebihinya. 


\section{Deskripsi Data Siklus}

1. Diskripsi prasiklus. Sebelum melaksanakan pembelajaran pada siklus I, peneliti menganalisis data awal hasil belajar siswa mata pelajaran Matematika. Data awal siswa ini diperoleh berdasarkan hasil ulangan harian pada pokok bahasan persamaan dan pertidaksamaan linier satu variabel . Bila disajikan dalam bentuk tabel, hasil belajar awal siswa kelas VII.7 sebelum diberikan tindakan adalah :

\section{Tabel 1: Hasil Belajar Awal Siswa Kelas VII.7}

Nilai 304050607080 tuntas

Jml siswa 258710414

Nilai rata rata 58,33

Ketuntasan $38,89 \%$

Jika melihat kondisi awal hasil belajar siswa di atas, ada 14 orang siswa yang mampu mencapai nilai KKM atau lebih, nilai rata-rata 58,33 ketuntasan klasikal 38,89\% sedangkan ketuntasan klasikal yang ditetapkan di SMPN 178 adalah $85 \%$.

1. Siklus I :

1) Tahap Perencanaan dilaksanakan 3 kali pertemuan materi pelajaran sesuai dengan GBPP matemtika SMP kurikulum 2013 Pada pertemuan ke-1 konsep Himpunan; pertemuan ke-2 menyatakan himpunan; pada pertemuan ke-3, diagram Venn, dilanjutkan tes formatif.Adapun persiapan dalam penelitian tindakan kalas ini meliputi:1)Membuat perangkat pembelajaran agar menarik dan mudah dipahami siswa; 2) Menyusun RPP dengan penerapan Model pembelajaran Koperatif tipe Student Teams Achievement Division (STAD), dilengkapi dengan lembar kerja terkontrol dan soal tes formatif sebanyak 10 nomer; 3) membuat lembar observasi pengamatan aktifitas pembelajaran untuk perserta didik dan guru.

2) Tahap pelaksanaan ,pertemuan pertama dilaksanakan pada hari rabu, 29 Agustus 2018. Peneliti memulai pelajaran dengan mengucapkan salam dan apersepsi. Peneliti menyampaikan tujuan pembelajaran, kemudian menjelaskan materi tentang konsep himpunan diselingi dengan tanya jawab.Pada tahap selanjutnya Peneliti membentuk kelompok diskusi yang terdiri dari 6 kelompok yang heterogen. Peneliti membagikan LKS, peserta didik mengerjakan selama 20 menit. Dan presentasi hasil diskusi kelompok serta kesimpulan dilanjutkan pada pertemuan ke 2.Pertemuan kedua, dilaksanakan pada hari selasa, 4 september 2018. Peneliti membuka pelajaran dengan memberi salam dan memeriksa kehadiran siswa, menyampaikan tujuan pembelajaran, menjelaskan cara menyatakan himpunan. Peserta didik berdiskusi mengerjakan lembar kerja terkontrol dalam kelompoknya, dilanjutkan presentasi kelompok. Peneliti memberikan penguatan tentang cara menyatakan himpunan dan memberikan apresiasi terhadap tiap tiap kelompok.

Pertemuan ketiga, dilaksanakan pada hari Rabu, 5 september 2018. Peneliti membuka pelajaran dengan memberi salam dan memeriksa kehadiran siswa menyampaikan tujuan pembelajaran sesuai dengan RPP. Peneliti mengarahkan kepada siswa untuk mendiskusikan cara membuat diagram Venn. Peneliti memantau jalannya diskusi dan menanggapi semua permasalahan yang muncul dari siswa.Peneliti bersama siswa membuat kesimpulan, dilanjutkan tes formatif siklus I.

3) Tahap Pengamatan, tindakan yang dilakukan peneliti dan kolaborator untuk melihat aktifitas peserta didik dalam mengikuti proses pembelajarandengan menggunakan model Koperatif tipe Student Teams Achievement Division (STAD) pada materi,konsep himpunan, menyatakan himpunan dan membuat diangram Venn, kemudian mendiskripsikan hal-hal yang terjadi selama kegiatan pembelajaran berlangsung. 


\begin{tabular}{|l|c|c|c|c|c|c|}
\hline Kelompok & 1 & 2 & 3 & 4 & 5 & 6 \\
\hline Nilai & 75 & 70 & 70 & 60 & 80 & 75 \\
\hline
\end{tabular}

Dari tabel diatas menunjukkan bahwa nilai diskusi kelompok pada siklus I yang sudah mencapai nilai KKM ada 5 kelompok, yang belum mencapai nilai KKM 1 kelompok Hal ini menunjukkan bahwa belum semua kelompok dapat bekerjasama untuk memahami konsep himpunan, oleh karena itu perlu adanya bantuan kepada kelompok yang belum mencapai nilai KKM supaya lebih aktif sehingga meningkatkan pemahaman terhadap konsep Himpunan. Berdasrkan hasil pengamatan, hasil belajar Matematika siswa kelas VII.7 pada siklus I dapat disajikan sebagai berikut ini:

Tabel 3: Hasil Belajar Siswa Kelas VII.7 Siklus I

Nilai 405060708090 tuntas

Jml siswa 258127221

Nilai rata rata 66,40

Ketuntasan 58,33\%

Hasil analisis data menunjukkan siswa yang mendapat nilai mencapai KKM atau lebih 21 orang nilai rata-rata siswa mencapai 66,40, berarti meningkat 8,07 dari hasil tes pra siklus, sedangkan ketuntasan mencapai 58,33\% berarti meningkat 13,89\% dari hasil tes pra siklus .

4) Tahap Refleksi 1)Pelaksanaan program pembelajaran belum maksimal sehingga Peneliti belum seluruhnya menerapkan pembelajaran secara maksimal (pengelolaan waktu belum maksimal); 2) masih ada siswa yang kurang aktif dan malu untuk bertanya; 3) siswa yang mencapai KKM atau lebih baru 58,33\%, padahal di SMP 178 ketuntasan klasikal $85 \%$.

Peneliti menyadari masih ada kekurangan-kekurangan yang dirasakan pada saat pembelajaran berlangsung. Oleh karena itu, peneliti berusaha memperbaiki kekurangankekurangan tersebut pada pertemuan berikutnya. Berdasarkan data dan hasil yang diperoleh kurang maksimal, maka peneliti merasa perluuntuk melakukan penelitian lanjutan pada siklus II dengan perencanaan dan pelaksanaan perbaikan berdasarkan hasil pengamatan dan refleksi yang dilakukan pada siklus I

\section{Siklus II.}

1) Tahap Perencanaan, Peneliti melakukan 3 kali pertemuan, materi pembelajaran yang disajikan yaitu pertemuan ke-1 bilangan kardinal, pertemuan ke-2 himpunan bagian dan pertemuan ke- 3 tes formatif siklus II. Berdasarkan hasil tindakan yang dilakukan pada siklus I maka peneliti dan kolaborator merumuskan rencana tindakan untuk siklus II. Perencanaan tindakan pada siklus II hampir sama denga siklus I namun ada perbaikan, meliputi:1) Memotivasi dan mengaktivkan siswa secara merata pada saat pembelajaran berlangsung ; 2) memberikan kesempatan bertanya lebih banyak pada siswa untuk menemukan sifat-sifat himpunan dan konsep himpunan bagian; 3) pengelolaan waktu dari kegiatan membuka pelajaran melakukan kegiatan inti dan menutup pelajaran perlu ditingkatkan.

2) Tahap Tindakan, berdasarkan perencanan yang disusun, peneliti menyampaikan materi pembelajaran tentang bilangan kardinal, himpunan bagian dan himpunan kuasa.Pertemuan pertama, dilaksakan pada hari Rabu, 12 September 2018. Peneliti memulai pembelajaran memberi salam kepada siswa, memeriksa kehadiran siswa, kebersihan ruangan kelas, dan memberikan motivasi kepada peserta didik. Peneliti melakukan apersepsi, mengingat kembali konsep himpunan. Peneliti mengkomunikasikan tujuan pembelajaran sesuai dengan RPP yaitu menyatakan bilangan kardinal dari suatu himpunan. Peneliti mengarahkan siswa duduk sesuai dengan kelompoknya, untuk mendiskusikan bilangan kardinal suatu himpunan. Peneliti mengarahkan siswa menarik kesimpulan untuk menemukan sifat-sifat himpunan . Pada pertemuan ini peran peneliti tekesan memberikan arahan, apabila siswa merasa kesulitan, peneliti selaku pemberi materi 
langsung memberikan bimbingan.Pada akhir pelajaran peneliti memberikan tugas kelompok untuk bahan diskusi berikutnya. Pertemuan kedua. Dilaksanakan pada hari Selasa, 18 September 2018 jam ke 1-2. Peneliti memulai pembelajaran memberi salam kepada siswa, memeriksa kehadiran siswa, kebersihan ruangan kelas, dan memberikan motivasi kepada siswa. Peneliti melakukan apersepsi, mengingat kembali bilangan kadinal suatu himpunan, menyampaikan tujuan pembelajaran sesuai dengan RPP yaitu himpunan bagian dari suatu himpunan, menyampaikan tujuan pembelajaran yang akan didiskusikan oleh masing-masing kelompok, Siswa mengerjakan LKS kemudian peneliti memberi kesempatan kepada kelompok untuk mempersiapkan diri melakukan presentasi dengan materi yang ada dalam LKS dengan waktu yang dibatasi sekitar 40 menit. Peneliti membimbing siswa melakukan tanya jawab tentang materi yang telah dipresentasikan. Peneliti memberikan apresiasi terhadap kelompok yang paling baik dan memberikan masukan terhadap kelompok yang belum baik. Pada pertemuan ini peneliti lebih banyak memberikan motivasi agar siswa berani bertanya dan menanggapi jawaban temannya, sehingga siswa yang bertanya semakin banyak dan siswa lebih dapat menyusun pertanyaan dengan kalimat yang baik. Pada pertemuan ini tampak sekali dalam diskusi keaktifan tiap kelompok dibandingkan pada siklus 1 , observer mengamati dan mencatat semua kegiatan. Peneliti mengakhiri kegiatan pembelajaran, memberikan apresiasi kepada kelompok yang bagus, dan mengingatkan kelompok yang belum presentasi untuk maju pada pertemuan ke 3 Pertemuan ketiga, dilaksanaka pada hari Rabu, 18 September 2018. Peneliti memulai pembelajaran memberi salam kepada siswa, memeriksa kehadiran siswa, kebersihan ruangan kelas, dan memberikan motivasi kepada siswa. Peneliti melakukan apersepsi, mengingat kembali tentang himpunan bagian dari suatu himpunan. Peneliti menyampaikan tujuan pembelajaran sesuai dengan RPP. Pembelajaran melanjutkan presentasi, peneliti mengarahkan siswa untuk berdiskusi materi himpunan kuasa sesuai dengan kelompok yang sudah dibentuk pada siklus I. Siswa mempresentasikan hasil diskusi kelompoknya, siswa lain menanggapi. Peneliti bersama siswa membuat kesimpulan. Siswa melaksanakan tes fomatif siklus II.

3) Tahap Pengamatan Hasil pengamatan observer pada siklus II dalam proses belajar mengajar adalah sebagai berikut: Siswa lebih aktif dalam diskusi kelompok, siswa yang mengajukan pertanyaan dan menjawab pertanyaan dari teman meningkat.

Tabel 4: Hasil Diskusi kelompok pada Siklus II

\begin{tabular}{l}
\hline Kelompok 123456 \\
\hline Nilai 859085808590 \\
\hline
\end{tabular}

Dari tabel diatas nilai diskusi kelompok sudah mencapai nilai KKM karena setiap kelompok mendapat nilai lebih dari 70, nilai terendah dalam diskusi kelompok 80 yang diperoleh oleh kelompok 4 dan nilai 90 oleh kelompok 2 dan 6 . Hal ini menunjukan bahwa setiap kelompok bisa bekerjasama antar anggotanya .

Tabel 5: Hasil Belajar Siswa Kelas VII.7 Siklus II

\begin{tabular}{l}
\hline Nilai 5060708090 tuntas \\
\hline Jml siswa 37128614 \\
Nilai rata rata 71,94 \\
Ketuntasan $72,22 \%$
\end{tabular}

Hasil analisis data hasil belajar menunjukkan siswa yang mencapai KKM atau lebih 26 orang, nilai rata-rata 71,9 ada peningkatan 5,54 dari siklus I $(66,4)$ ketuntasan klasikal baru mencapai $72,20 \%$ ada peningkatan 13,89 dari siklus I ( $61,11 \%$ ).Pada siklus II nilai rata-rata sudah mencapai KKM tetapi ketuntasan klasikal belum mencapai $85.00 \%$. 
4) Tahap Refleksi : keaktifan siswa meningkat, pelaksanaan program pembelajaran belum maksimal, terlihat dari siswa yang mencapai KKM baru 72,20\%, sedangkan di SMP 178 ketuntasan klasikal minimal mencapai $85 \%$.

Peneliti menyadari masih ada kekurangan-kekurangan yang dirasakan pada saat pembelajaran berlangsung. Oleh karena itu, peneliti berusaha memperbaiki kekurangan-kekurangan tersebut pada pertemuan berikutnya. Berdasarkan data dan hasil yang diperoleh kurang maksimal, maka peneliti meras perlunya dilakukan penelitian lanjutan pada siklus III dengan perencanaan dan pelaksanaan perbaikan berdasarkan hasil pengamatan dan refleksi yang dilakukan pada siklus II.

\section{Diskripsi Data Siklus III}

1) Tahap Perencanaan Berdasarkan refleksi pada siklus II, pada siklus III peneliti akan memberikan tindakan:Penelitian tindakan kelas ini menggunakan pola kerja kolaborator antara peneliti dengan teman sejawat (guru matematika). Adapun persiapan dalam penelitian tindakan kelas ini meliputi: membuat perangkat pembelajaran agar menarik dan mudah dipahami siswa.Menyusun RPP materi himpunan irisan, gabungan, komplementer dan selisih dengan penerapan Model pembelajaran Koperatif tipe STAD. Merencanakan kegiatan belajar mengajar dengan menggunakan lembar kerja terkontrol.Menyamakan persepsi dalam pelaksanaan tindakan yang akan dilaksanakan di kelas. Mengatur tempat duduk siswa secara kelompok. Untuk memperoleh data tentang kemajuan hasil belajar, Peneliti peneliti dengan teman kolaborator menyusun soal tes formatif 20 nomer

2) Tahap Pelaksanaan, pertemuan pertama, dilaksanakan pada hari Selasa, 25 September 2018. Peneliti memulai pembelajaran dengan mengucapkan salam dan memeriksa kehadiran siswa, Peneliti menyampaikan tujuan pembelajaran tentang irisan himpunan kemudian menjelaskan materi tersebut diselingi dengan tanya jawab. Siswa duduk sesuai pada klompoknya, peneliti membagikan LKS dengan sejumlah pertanyaan yang berhubungan irisan himpunan, siswa mengerjakan selama 20 menit. Dan presentasi hasil diskusi kelompok.Pertemuan kedua, dilaksanakan pada hari Rabu,26 September 2018. Peneliti membuka pelajaran dengan memberi salam dan memeriksa kehadiran siswa. Kegiatan melanjutkan presentasi kelompok, peneliti memuji kelompok yang sudah yang melakukan presentasi. Setelah selesai diskusi, peneliti memberikan penguatan tentang himpunan irisan, gabungan, komplemen dan selisih. Peneliti mengakhiri diskusi dengan menyimpulkan materi yang di bahas dan memberikan apresiasi terhadap kelompok yang bagus hari itu dengan bertepuk tangan dan siswa terlihat senang. Pada tahap terakhir pembelajaran peneliti menginformasikan untuk mempersiapka tes formatif pada pertemuan berikutnya.Pertemuan ketiga, dilaksanakan pada hari Selasa, 2 Oktober 2018, Uutuk mengukur hasil belajar siswa peneliti mengadakan tes formatif siklus III. Tempat duduk siswa diatur sedemikian rupa untuk menghindari adanya kerjasama antar siswa. Bentuk soal berupa soal pilihan ganda sebanyak 20 butir soal.

3) Tahap Pengamatan

Tabel 6. Hasil Diskusi kelompok pada Siklus III

Kelompok 123456

Nilai 90100908590100

Dari tabel diatas diketahui bahwa nilai diskusi kelompok pada siklus III sudah mencapai nilai KKM karena setiap kelompok mendapat nilai lebih dari 70. Hal ini menunjukan bahwa setiap kelompok mengalami peningkatan dibandingkan pada siklus II 
Nilai 60708090100 tuntas

Jml siswa 313107433

Nilai rata rata 78,89

Ketuntasan $91,67 \%$

Hasil analisis tes formatif III menunjukkan siswa yang memperoleh nilai yang mencapai KKM atau lebih 33 orang nilai rat-rata siswa 79,86 ada peningkatan 6,95 dari siklus II (ketuntasan klasikal mencapai 91,67\% ada peningkatan 19,45 dari siklus II Pada siklus III nilai rata-rata sudah mencapai KKM ,ketuntasan klasikal sudah melebihi ketuntasan yang ditetapkan oleh sekolah $85.00 \%$.

Dari data tersebut menunjukkan bahwa kegiatan pembelajaran pada materi himpunan dengan model pembelajaran Koperatif tipe STAD dapat mengaktifkan siswa dan meningkatlan hasil belajar.

4) Tahap Refleksi, pada siklus III kegiatan pembelajaran sudah terlihat efektif, kerja sama antar siswa dalam kelompoknya sangat baik dan minat belajar siswa meningkat.

\section{B. Pembahasan Hasil Penelitian}

Berdasarkan hasil pengamatan dan evaluasi yang dilaksanakan selama 3 siklus, hasil diskusi kelompok dan belajar siswa mengalami peningkatan. Hasil belajar siswa dapat dilihat dari skor evaluasi siklus, mulai kondisi awal sampai siklus III.

\section{Hasil Diskusi Kelompok}

Bila disajikan dalam bentuk grafik, hasil diskusi kelompok siswa kelas VII.7 dari siklusI sampai siklus III setelah diberikan tindakan adalah sebagai berikut :

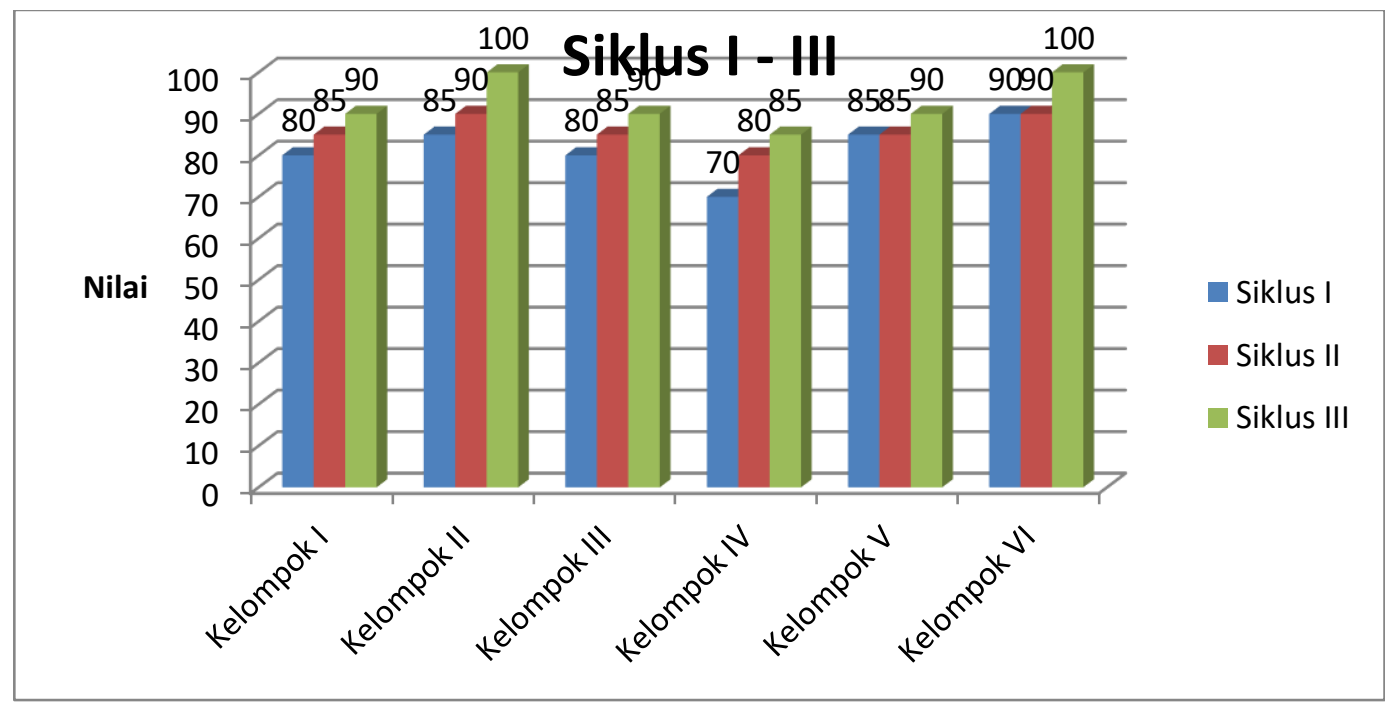

\section{Grafik Hasil Diskusi Kelompok Siklus I, II, dan III kelas VII.7}

Berdasarkan grafik hasil diskusi kelompok siklus I, II, dan III menunjukkan kelompok 1, 2, 3, dan 4 setiap siklusnya mengalami peningkatan, kelompok 5 dan 6 pada siklus II tidak mengalami peningkatan, pada siklus III mengalami peningkatan. Dari hasil tersebut pemberian tindakan pembelajaran Matematika dengan model Koperatif tipe STAD pada materi Himpunan dapat meningkatkan kerja sama dan hasil belajat siswa kelas VII.7 SMPN 178 Jakarta.

Tabel 8: Perbandingan Rata-rata Nilai, Daya Serap, KKM dan Ketutasan Hasil Belajar Pra siklus, Siklus I, Siklus II dan Siklus III

\begin{tabular}{|l|l|l|l|l|l|}
\hline \multirow{2}{*}{ No } & \multirow{2}{*}{ Kriteria } & \multicolumn{4}{|c|}{ Siklus } \\
\cline { 3 - 5 } & Prasiklus & I & II & III \\
\hline
\end{tabular}




\begin{tabular}{|l|l|c|c|c|c|}
\hline 1 & Rata-rata Nilai & 58,33 & 66,40 & 71,94 & 78,89 \\
2 & Daya serap (\%) & 58,33 & 66,40 & 71,94 & 78,89 \\
3 & KKM & 70 & 70 & 70 & 70 \\
4 & Ketuntasan (\%) & 38,89 & 58,33 & 72,22 & 91,67 \\
\hline
\end{tabular}

Berdasarkan deskripsi hasil pengamatan dan evaluasi siklus pada tabel 4.7 menunjukkan bahwa peningkatan nilai rata-rata dari pra siklus ke siklus I adalah 8,07, siklus 1 ke siklus II adalah 5,54 dan siklus II ke siklus III adalah 6,95. Peningkatan ketuntasan dari prasiklus ke siklus I sebesar 19,44\%, siklus I ke sklus II sebesar 13,89\% dan peningkatan siklus II ke siklus III sebesar 19,45\%. Dari hasil tersebut pemberian tindakan pembelajaran Matematika dengan model Koperatif tipe STAD pada materi Himpunan dapat meningkatkan secara signifikan hasil belajar siswa kelas VII.7 SMPN 178 Jakarta, walaupun masih ada 3 orang siswa yang belum mencapai Kriteria Ketuntasan Minimal (KKM). Oleh karena itu, tindakan perbaikan tidak akan dilaksanakan pada siklus berikutnya. Hal ini disebabkan kurangnya waktu pembelajaran.

Berdasarkan analisa diatas model pembelajaran kooperatif mampu menumbuhkan rasa tanggung jawab, baik individu maupun kelompok dan dapat meningkatkan hasil belajar siswa, sesuai dengan pendapat Isjoni (dalam Donni Juni Priansa, 2017: 320)

\section{KESIMPULAN}

Berdasarkan deskripsi hasil pengamatan dan evaluasi siklus di atas menunjukkan bahwa pemberian tindakan dalam pembelajaran Matematika pada materi himpunan dengan model pembelajaran kooperatif tipe STAD (Student Teams Achievement Division) dapat disimpulkan antara lain dapat meningkatkan aktifitas belajar siswa, dapat meningkatkan pemahaman konsep matematika. .Adanya peningkatan jumlah siswa yang mendapatkan nilai KKM atau lebih dari siklus I, II, dan III. Secara klasikal peningkatan hasil belajar siswa sangat tergantung dari keterlibatan peneliti dalam mendampingi siswa ketika mereka belajar.

Berdasarkan implikasi yang telah diutarakan, peneliti mengemukakan beberapa saran bagi guru Matematika, hendaknya melaksanakan pembelajaran Matematika secara optimal dengan membuat perencanaan yang lebih efektif serta memperhitungkan faktor internal yang dimiliki siswa dan faktor eksternal yang diterima siswa selama pembelajaran. Gunakan model pembelajaran sesuai dengan materi yang akan disampaikan sehingga memudahkan siswa menemukan pengetahuan baru,memperoleh konsep dan ketrampilan yang dapat memecahkan masalah yang dihadapinya. Hendaknya selalu kreatif dan inovatif dalam mencari metodemetode pembelajaran yang bervariasi sehingga dapat meningkatkan hasil belajar siswa.

\section{DAFTAR PUSTAKA}

Angga, Kristiyajati. (2016). Modul Pelatihan Matematika SMA Kelompok Kompetensi H Pengembangan Kurikulum Matematuka. Jakarta: Kementerian Pendidikan dan Kebudayaan.

Dimyati dan Mudjiono. ( 2006). Belajar dan Pembelajaran. Jakarta: PT Rineke Cipta.

Kemendikbud. (2013). Modul Pelatihan Implementasi Kurikulum Jakarta: Kemendikbud Press.

Kunandar. (2013). Penilaian Autentik. Jakarta: P.T. Raja Grafindo Persada

PPPPTK, Matematika. (2016). Modul Diklat Guru Pembelajar: Teori Belajar Matematika. Yogyakarta

Priansa, Juni, Doni. (2017). Bimbingan Strategi \& Model Pembelajaran. Bandung: CV Pustaka Setia

Setiani \& Priansa. (2015). Manajemen Peserta Didik dan Model Pembelajaran: Cerdas, Kreatif dan Inovatif. Bandung: CV. Alfabeta.

Suryabrata,Sumadi. (2004 ). Metode Penelitan. Jakarta: P.T. Raja Grafindo Persada..

Wijayanti, Tri. (2016). Pemanfaatan Media Gambar Untuk Meningkatkan Hasil Belajar Siswa. Wiriaatmadja, Rochiati. (2012). Metode Penelitian Tindakan Kelas. Bandung: PT Remaja Rosdakary. 
Yudhawati, Ratna, and Dany, Haryanto. (2011). Teori-Teori Dasar Psikologi Pendidikan. Jakarta: PT. Prestasi Pustakaraya. 